\title{
Role of the somatostatin system in contextual fear memory and hippocampal synaptic plasticity
}

\author{
Christian Kluge, ${ }^{1,4,5}$ Christian Stoppel, ${ }^{2,4,5}$ Csaba Szinyei, ${ }^{1}$ Oliver Stork, ${ }^{2,3}$ \\ and Hans-Christian Pape ${ }^{1,6}$ \\ ${ }^{1}$ Institute of Physiology I (Neurophysiology), Westfälische Wilhelms-University Münster, 48149 Münster, Germany; \\ ${ }^{2}$ Institute of Physiology, Otto-von-Guericke University Magdeburg, 39120 Magdeburg, Germany; ${ }^{3}$ Department of Molecular \\ Neurobiology, Institute of Biology and Center for Behavioural Brain Sciences, Otto-von-Guericke University Magdeburg, \\ 39120 Magdeburg, Germany
}

\begin{abstract}
Somatostatin has been implicated in various cognitive and emotional functions, but its precise role is still poorly understood. Here, we have made use of mice with somatostatin deficiency, based upon genetic invalidation or pharmacologically induced depletion, and Pavlovian fear conditioning in order to address the contribution of the somatostatin system to associative fear memory. The results demonstrate an impairment of foreground and background contextual but not tone fear conditioning in mice with targeted ablation of the somatostatin gene. These deficits were associated with a decrease in long-term potentiation in the CAl area of the hippocampus. Both the behavioral and the electrophysiological phenotypes were mimicked in wild-type mice through application of the somatostatin-depleting substance cysteamine prior to fear training, whereas no further deficits were observed upon application in the somatostatin null mutants. These results suggest that the somatostatin system plays a critical role in the acquisition of contextual fear memory, but not tone fear learning, and further highlights the role of hippocampal synaptic plasticity for information processing concerning contextual information.
\end{abstract}

Somatostatin is a cyclic polypeptide widely distributed in the mammalian central nervous system (Reisine and Bell 1995) and functionally implicated in a variety of physiological processes, such as neurotransmission, hormone secretion, and tissue proliferation (for recent review, see Moller et al. 2003). Two biologically active isoforms of somatostatin exist, namely a tetradecapeptide (SST-14) and its N-terminally extended form (SST-28), both of which bind to $G$ protein-coupled receptors with high affinity. In the hippocampus, somatostatin-14 is present in distinct interneurons and acts in concert with $\gamma$-aminobutyric acid (GABA), with which it is colocalized and sometimes co-released (for reviews, see Binaschi et al. 2003; Baraban and Tallent 2004). Similarly, in the amygdala, somatostatin has been localized to a defined population of GABAergic interneurons, although the colocalization is not exclusive in that principal neurons also express the peptide (McDonald and Mascagni 2002; Sosulina et al. 2006). The overall influence of the somatostatin system in these structures is an inhibition of excitatory synaptic transmission, mediated to a significant part by an increase in $\mathrm{K}^{+}$conductance and a decrease in $\mathrm{Ca}^{2+}$ conductance at post- and presynaptic sites (Baraban and Tallent 2004). In view of the critical role of both the hippocampus and the amygdala in associative (fear) memory formation, it comes as no surprise that an involvement of somatostatin has been implicated in amygdala- and hippocampusdriven cognitive and emotional functions (Vecsei and Widerlov 1990; Schettini 1991). Animal studies, for example, have shown a correlation between memory performance in hippocampusdependent tasks and the amount of endogenously expressed somatostatin (Nilsson et al. 1993; Nakagawasai et al. 2000, 2003) and recently also in the pathology of Alzheimer's disease (Davies

\footnotetext{
${ }^{4}$ These authors contributed equally to this work.

5 Present address: Department of Neurology II, Otto-von-Guericke University Magdeburg, Leipziger Str. 44, 39120 Magdeburg, Germany. ${ }^{6}$ Corresponding author.

E-mail papechris@ukmuenster.de; fax 49-251-8355551.

Article is online at http://www.learnmem.org/cgi/doi/10.1101//m.793008.
}

et al. 1980; Saito et al. 2005), an ailment in which hippocampal memory deficits are a prominent clinical feature. However, the precise role of somatostatin in these processes is still poorly understood.

In the present study, we investigated somatostatin function in different stages of fear memory formation. Our experimental design makes use of (1) somatostatin deficiency in mice, both upon deletion of the somatostatin gene (Zeyda et al. 2001) and through pharmacologically induced somatostatin depletion in different memory stages (Szabo and Reichlin 1981), and (2) Pavlovian fear conditioning as an established model of associative fear learning and memory that allows us to address and dissect the contribution of amygdalar and hippocampal processes (LeDoux 2000; Phelps and LeDoux 2005). The behavioral investigations are further complemented by (3) analyses of hippocampal synaptic plasticity in vitro providing insight into cellular mechanisms underlying the observed learning phenomena. By means of pharmacological depletion of somatostatin complementary to somatostatin gene invalidation, we were able to demonstrate the selective disturbance of the acquisition, but not consolidation, of hippocampus-dependent contextual fear memory and its association with deficits in hippocampal synaptic plasticity.

\section{Results}

\section{Conditioned fear responses to context and cue}

in somatostatin gene-invalidated mice

Mice with an invalidated somatostatin gene (SST ${ }^{-1-}$ ), as well as heterozygous ( $\mathrm{SST}^{+/-}$) and wild-type $\left(\mathrm{SST}^{+/+}\right)$littermates, were fear conditioned in contextual and auditory cued fear conditioning paradigms, and conditioned responses to the foreground shock context, background context, the conditioned tone (CS+), and neutral tone (CS - ) were determined to assess fear memory. The conditioned response generally took a graduated development of different behavioral components, and, in accordance 
with previous observations (Laxmi et al. 2003), we considered freezing as one adequate behavioral response indicating fear in different test situations.

\section{Contextual conditioning}

Freezing responses upon foreground contextual conditioning were statistically analyzed using three-way RANOVA, with genotype and gender as independent factors and test sessions (baseline and retrieval sessions 1-3) as a within-subject factor. Data revealed a significant main effect of repeated testing $\left(F_{(3,18)}=73.403 ; P<0.0001\right)$ and an interaction of genotype and test session $\left(F_{(6,38)}=4.374 ; P<0.002\right)$. Because of the significant genotype $\times$ test session interaction, each training session was analyzed separately by ANOVA with genotype as the independent factor. While all groups displayed similar baseline behavior, the time spent freezing was significantly different across genotypes during all retrieval sessions (Fig. 1A; retrieval 1: $F_{(2,23)}=3.596, P<0.05$; retrieval $2: F_{(2,23)}=18.688, P<0.0001$; retrieval 3: $\left.F_{(2,23)}=17.558, P<0.0001\right)$. Post hoc analysis revealed a gene dosage-dependent effect of genotype on freezing behavior. Firstly, $\mathrm{SST}^{-/-}$mice showed significantly less freezing compared with $\mathrm{SST}^{+/-}$and $\mathrm{SST}^{+/+}$mice throughout all retrieval sessions (mean \pm SEM: $3.50 \pm 0.95$ for $\mathrm{SST}^{-1-}$ mice vs. $8.23 \pm 1.37$ for $\mathrm{SST}^{+/-}$and $7.94 \pm 1.78$ for $\mathrm{SST}^{+/+}$mice for retrieval session 1). And secondly, the difference in freezing behavior also proved significant for comparison of $\mathrm{SST}^{+/-}$and $\mathrm{SST}^{+/+}$ mice for retrieval session 2 (Fig. $1 \mathrm{~A}$; mean \pm SEM: $4.26 \pm 0.87$ for $\mathrm{SST}^{-/-}$mice vs. $10.92 \pm 1.72$ for SST ${ }^{+/-}$and $17.22 \pm 1.37$ for $\mathrm{SST}^{+/+}$mice) and session 3 (Fig. $1 \mathrm{~A}$; mean \pm SEM: $5.88 \pm 1.07$ for $\mathrm{SST}^{-/-}$mice vs. $12.28 \pm 1.25$ for $\mathrm{SST}^{+/-}$and $17.28 \pm 1.57$ for $\mathrm{SST}^{+/+}$mice). Thus, all groups displayed a significant learning effect during retrieval session 1 as compared with baseline $\left(P<0.02\right.$ for $\mathrm{SST}^{-1-}$ mice, $P<0.0002$ for $\mathrm{SST}^{+/-}$mice, and

A

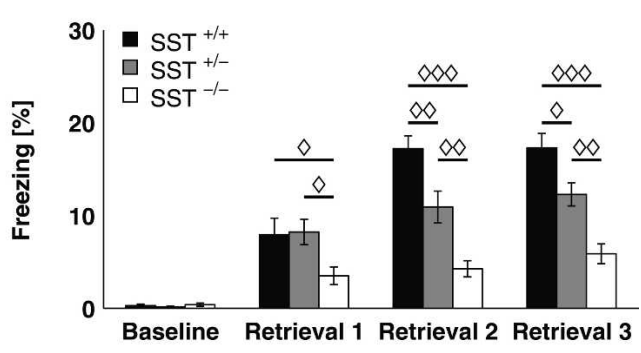

B

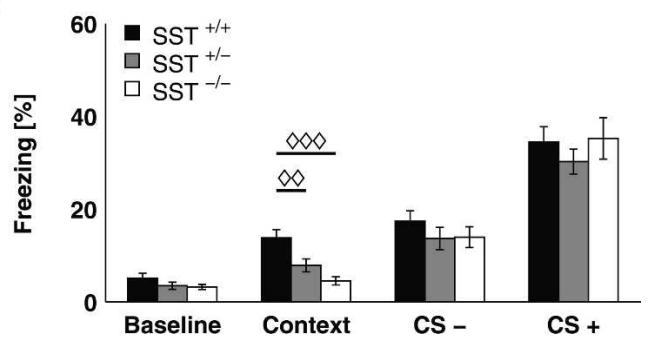

Figure 1. SST mutation disrupts both foreground and background contextual fear memory in a gene dosage-dependent manner. $(A)$ In foreground contextual fear conditioning, $\mathrm{SST}^{-1-}$ mice $(n=8)$ showed significantly decreased freezing compared with $\mathrm{SST}^{+/-}(n=10)$ and $\mathrm{SST}^{+/+}$mice $(n=8)$. Furthermore, a significant deficit was also evident for $\mathrm{SST}^{+/-}$animals during retrieval sessions 2 and 3 . (B) After auditory cued fear conditioning, SST ${ }^{-1-}$ mice $(n=13)$ and $\mathrm{SST}^{+/-}$mice $(n=16)$ displayed significantly less freezing to the background context when compared with $\mathrm{SST}^{+/+}$mice $(n=12)$, whereas groups did not differ in their freezing behavior during CS - and CS+ presentation. All data depicted as mean \pm SEM; $(\diamond) P<0.05,(\diamond \diamond) P<0.01,(\diamond \diamond \diamond) P<0.001$ in all plots.
$P<0.003$ for $\mathrm{SST}^{+/+}$mice), whereas a further increase in freezing levels during retrieval session 2 was significant only for $\mathrm{SST}^{+/+}$ mice $\left(P<0.005\right.$ for $\mathrm{SST}^{+/+}$mice, $P=0.16$ for $\mathrm{SST}^{+/-}$mice, and $P=0.45$ for $\mathrm{SST}^{-1-}$ mice).

\section{Cued conditioning}

Upon explicit tone fear conditioning, freezing behavior was statistically evaluated by three-way RANOVA with genotype and gender as independent factors and test condition (baseline, background context, $\mathrm{CS}-$, and $\mathrm{CS}+$ ) as the repeated factors. There was a significant main effect for repeated testing $\left(F_{(3,33)}=83.708\right.$, $P<0.0001)$ and a significant interaction between genotype and test condition $\left(F_{(6,68)}=5.246, P<0.0002\right)$, as well as between gender and test condition $\left(F_{(3,33)}=10.861, P<0.0001\right)$, whereas no genotype $\times$ gender interaction $\left(F_{(6,68)}=0.905, P=0.50\right)$ was observed. Therefore, each test condition was analyzed separately by ANOVA with genotype as the independent factor. Baseline behavior, as well as freezing upon CS - and CS+ presentation, did not differ between groups, whereas there was a significant effect of genotype on freezing to the background context $\left(F_{(2,23)}=10.921, P<0.0003\right)$. Post hoc analysis revealed a significant difference between genotypes, with similar gene dosage dependency as in the contextual fear conditioning experiment (Fig. $1 \mathrm{~B}$; mean \pm SEM: $4.53 \pm 0.89$ for $\mathrm{SST}^{-1-}$ mice vs. $7.87 \pm 1.40$ for $\mathrm{SST}^{+/-}$and $13.83 \pm 1.74$ for $\mathrm{SST}^{+/+}$mice). All groups showed increased freezing upon CS - and CS+ presentation compared with their baseline freezing values $(P<0.0001$ for all groups), as revealed by separate analysis of each group by RANOVA. In contrast, increased freezing upon background context re-exposure compared with baseline was evident only in $\mathrm{SST}^{+/+}(P<0.002)$ and $\mathrm{SST}^{+/-}$mice $(P<0.001)$, whereas SST ${ }^{-1-}$ mice displayed no learning effect $(P=0.91)$.

\section{Conditioned fear responses in mice after cysteamine-induced somatostatin depletion}

Next, conditioned fear responses were assessed in C57Bl/6 mice after somatostatin had been depleted through systemic (i.p.) application of cysteamine. Three groups of animals were compared: those that received an injection of cysteamine at $50 \mathrm{mg} / \mathrm{kg}$ or 150 $\mathrm{mg} / \mathrm{kg}$, or of saline. Substances were applied $4 \mathrm{~h}$ prior to fear conditioning, in order to achieve a maximum of somatostatin depletion (Szabo and Reichlin 1981; Haroutunian et al. 1987; Cook et al. 1989) during memory acquisition. All pharmacological experiments were performed with the tone fear-conditioning paradigm, and freezing in response to the background context, CS+, and CS - were assessed. RANOVA with pharmacological treatment as the independent factor and test condition as the repeated factor revealed a significant main effect for repeated testing $\left(F_{(3,24)}=54.559, P<0.0001\right)$ and a significant treatment $\times$ test condition interaction $\left(F_{(6,50)}=3.442\right.$, $P<0.007)$. ANOVAs performed separately for each test condition showed no differences in baseline freezing or upon CS - and CS+ exposure between the three groups, but a statistically significant effect of treatment on background context behavior $\left(F_{(2,26)}=11.148, P<0.0004\right)$ was observed (Fig. 2A). Post hoc comparison revealed significant differences between groups, with a dose-dependent reduction of mean freezing duration (Fig. $2 \mathrm{~A}$; mean \pm SEM: $2.47 \pm 0.95$ for the $150 \mathrm{mg} / \mathrm{kg}$ group, $5.22 \pm 1.02$ for $50 \mathrm{mg} / \mathrm{kg}$ treatment, and $9.60 \pm 1.11$ for saline controls). This response pattern was strikingly similar to that observed in mice with genetically induced somatostatin deficiency (cf. Figs. 1B and 2A). Separate RANOVAs for each group revealed significantly increased freezing upon the CS $-(P<0.01$ for each group) and $\mathrm{CS}+(P<0.0001$ for each group) compared with baseline. During background context re-exposure, only sa- 
A

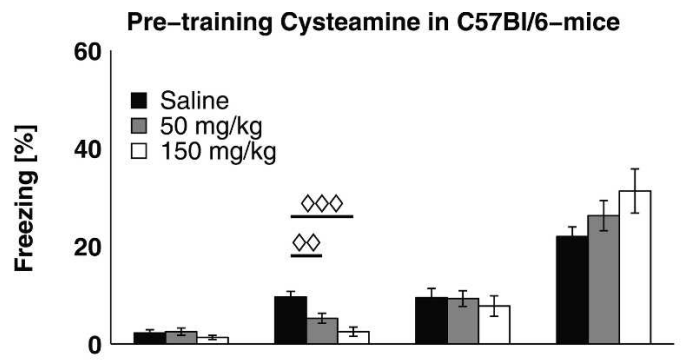

B

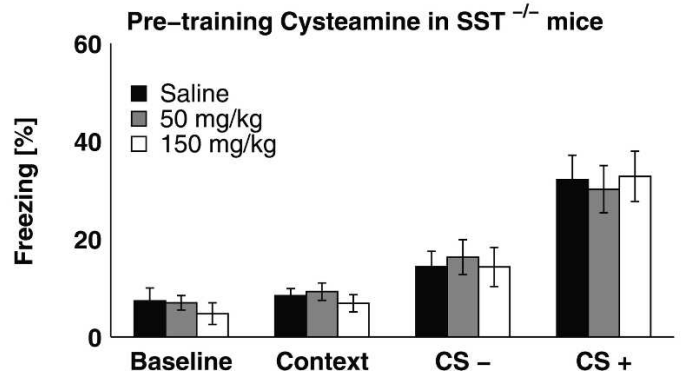

C

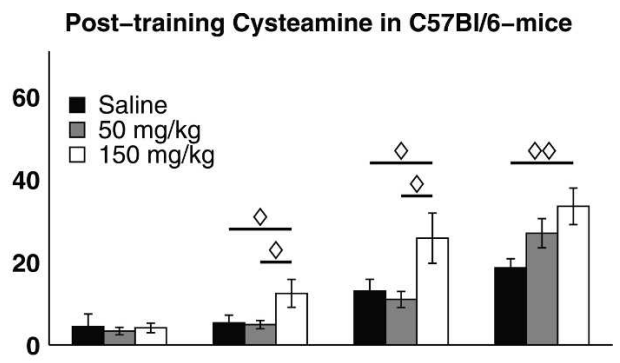

D

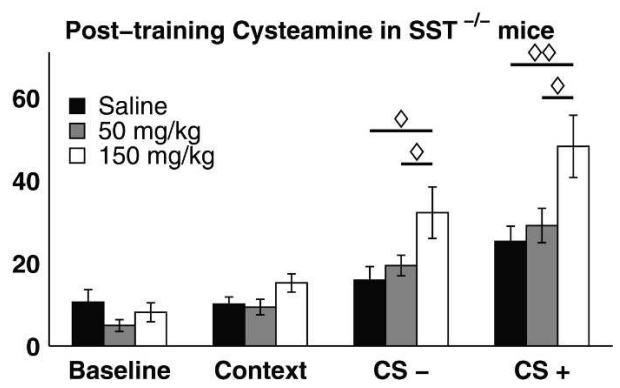

Figure 2. Acute somatostatin depletion with cysteamine dose-dependently reduces contextual fear memory, while post-training cysteamine induces an unspecific enhancement of fear responses. (A) Pre-training cysteamine treatment (50 mg/kg, $n=10$; and $150 \mathrm{mg} / \mathrm{kg}, n=8)$ dose-dependently led to a reduction of conditioned freezing to the background context in C57BI/6 mice, when compared with saline-treated mice $(n=10)$. In contrast, all groups showed a comparable amount of freezing upon CS - and CS+ re-exposure. (B) The freezing duration of SST ${ }^{-1-}$ mice was unaffected by cysteamine application prior to training regardless of the retrieval type studied (context, $C S-$, and $C S+; n=9$ for all groups). (C) C57BI/6 mice treated post-training with $150 \mathrm{mg} / \mathrm{kg}$ cysteamine $(n=11)$ displayed significantly increased freezing during all parts of the retrieval session (context, CS - , and CS+), when compared with saline-controls $(n=10)$. This difference was also evident for context and CS - re-exposure when animals treated with 150 $\mathrm{mg} / \mathrm{kg}$ were compared with the group receiving $50 \mathrm{mg} / \mathrm{kg}$ cysteamine $(n=11)$. (D) Similar to wild-type animals, $\mathrm{SST}^{-1-}$ mice also exhibited generally increased freezing behavior during context, $\mathrm{CS}-$, or CS+ exposure, when treated with $150 \mathrm{mg} / \mathrm{kg}$ cysteamine immediately after training (cf. $C ; n=9$ for all groups). All data depicted as mean \pm SEM; $(\diamond) P<0.05,(\diamond)) P<0.01,(\diamond \diamond \diamond) P<0.001$ in all plots.

line-treated animals showed increased freezing behavior $(P<0.0002)$, whereas both the $50 \mathrm{mg} / \mathrm{kg}$ and the $150 \mathrm{mg} / \mathrm{kg}$ cysteamine-treated animals did not display this learning effect ( $P=0.08$ and $P=0.188$, respectively) compared with baseline. In order to control for potential effects of cysteamine other than somatostatin depletion (Millard et al. 1983; Pitkanen et al. 1989), cysteamine was administered to $\mathrm{SST}^{-1-}$ mice $4 \mathrm{~h}$ before auditory cued fear conditioning and animals were tested $24 \mathrm{~h}$ later. In this experiment, RANOVA revealed a significant main effect of repeated testing on conditioned freezing behavior $\left(F_{(3,22)}=29.374\right.$, $P<0.0001)$ but no interaction between treatment and test condition $\left(F_{(6,46)}=0.221, P=0.96\right)$. Independent ANOVAs for each session revealed no effects of treatment on freezing behavior regardless of the training session (Fig. 2B). As before in $\mathrm{SST}^{-1-}$ mice (see Fig. 1B), all groups displayed significantly increased freezing during $\mathrm{CS}-(P<0.002$ for all groups $)$ and $\mathrm{CS}+$ presentation $(P<0.002$ for each treatment), but not upon context exposure $(P=0.46$ for $150 \mathrm{mg} / \mathrm{kg}, P=0.16$ for $50 \mathrm{mg} / \mathrm{kg}$, and $P=0.69$ for saline treatment) in comparison with baseline freezing values.

To differentiate between cysteamine effects on memory acquisition and consolidation, the drug was applied to $\mathrm{C} 57 \mathrm{Bl} / 6$ mice $10 \mathrm{~min}$ after fear conditioning training. The RANOVA revealed a significant main effect of repeated testing $\left(F_{(3,27)}=44.312, P<0.0001\right)$ and a significant interaction between treatment and test condition $\left(F_{(6,56)}=2.488, P<0.04\right)$. Separate ANOVAs for each session showed that, besides equivalent baseline behavior, groups differed in their freezing behavior during all parts of the retrieval session (Fig. 2C; for context: $F_{(2,29)}=3.404, P<0.05$; for $\mathrm{CS}-: F_{(2,29)}=3.922, P<0.04$; for CS+: $\left.F_{(2,29)}=4.248, P<0.03\right)$. Post hoc analysis revealed that 150 $\mathrm{mg} / \mathrm{kg}$ cysteamine led to significantly increased freezing in response to background context, CS - , and CS+ exposure, as compared with the $50 \mathrm{mg} / \mathrm{kg}$ group and saline controls, suggesting a generalized anxiety-like response (Fig. 2C; context re-exposure: $12.45 \pm 3.36$ for the $150 \mathrm{mg} / \mathrm{kg}$ group, $4.89 \pm 1.02$ for $50 \mathrm{mg} / \mathrm{kg}$, $5.33 \pm 1.02$ for saline controls; $\mathrm{CS}-$ re-exposure: $25.78 \pm 6.07$ for $150 \mathrm{mg} / \mathrm{kg}, 10.98 \pm 1.93$ for $50 \mathrm{mg} / \mathrm{kg}$, and $13.04 \pm 2.81 \mathrm{for}$ saline controls; CS+ re-exposure: $33.49 \pm 4.41$ for $150 \mathrm{mg} / \mathrm{kg}$, $26.99 \pm 3.54$ for $50 \mathrm{mg} / \mathrm{kg}, 18.60 \pm 2.24$ for saline controls; $P<0.05$ for all comparisons). In fact, application of cysteamine to $\mathrm{SST}^{-1-}$ mice 10 min after training yielded a similar behavioral pattern (Fig. 2D). A significant main effect for repeated testing $\left(F_{(3,22)}=33.207, P<0.0001\right)$ and a treatment $\times$ test condition interaction $\left(F_{(6,46)}=2.302, P<0.05\right)$ were revealed by two-way RANOVA. Separate ANOVAs showed that groups differed significantly in their behavior during CS $-\left(F_{(2,24)}=3.975, P<0.04\right.$; mean \pm SEM: $32.21 \pm 6.23$ for the $150 \mathrm{mg} / \mathrm{kg}$ group, $19.42 \pm 2.49$ for $50 \mathrm{mg} / \mathrm{kg}$, and $15.90 \pm 3.26$ for saline controls) and CS $+\left(F_{(2,24)}=5.212, P<0.02\right.$; mean \pm SEM: $48.23 \pm 7.52$ for the $150 \mathrm{mg} / \mathrm{kg}$ group, $29.08 \pm 4.16$ for $50 \mathrm{mg} / \mathrm{kg}$, and $25.28 \pm 3.63$ for saline controls), whereas this difference failed the significance criterion for contextual memory retrieval $\left(F_{(2,24)}=2.662, P=0.09\right.$; mean \pm SEM: $15.22 \pm 2.21$ for the 150 $\mathrm{mg} / \mathrm{kg}$ group, $9.37 \pm 1.90$ for $50 \mathrm{mg} / \mathrm{kg}$, and $10.10 \pm 1.71$ for saline controls). Post hoc analysis revealed significant differences between groups in a similar manner as observed in C57Bl/6 mice receiving post-training cysteamine treatment (cf. Fig. 2, C and D).

\section{Properties of hippocampal synaptic transmission} in SST $^{-I-}$ mice

Synaptic transmission and plasticity within and between the amygdala and the hippocampus are considered key elements in information processing related to contextual fear conditioning (Maren and Quirk 2004). Furthermore, synaptic transmission in 
the hippocampus is modulated by somatostatin and is affected by sst2 gene invalidation (Matsuoka et al. 1991a,b; Viollet et al. 2000; Rostampour et al. 2002b). Therefore, we next compared the synaptic transmission characteristics of the Schaffer-collateralCA1 system in $\mathrm{SST}^{+/+}$and $\mathrm{SST}^{-/-}$mice in slice preparations of the hippocampus in vitro. The Schaffer-collaterals were locally stimulated, and responses in the CA1 stratum radiatum were recorded as field excitatory postsynaptic potentials (fEPSPs). Basal synaptic transmission, determined as input-output curves, was not significantly different between genotypes (Fig. 3A). Furthermore, no difference between $\mathrm{SST}^{-1-}$ and $\mathrm{SST}^{+/+}$mice was observed in facilitation of synaptic responses to paired stimuli (varying the interpulse interval between 50 and $500 \mathrm{msec}$ ), indicating that this type of short-term synaptic plasticity is not affected by somatostatin deficiency (Fig. 3B). In contrast, LTP of synaptic responses after tetanic stimulation were significantly impaired in $\mathrm{SST}^{-/-}$mice as compared with $\mathrm{SST}^{+/+}$littermates (Fig. 4A). Twenty minutes after induction of stable LTP, the relative increase of the initial slope of the fEPSP amounted to $178.05 \% \pm 0.088 \%$ in $\mathrm{SST}^{+/+}$and to $142.17 \% \pm 0.062 \%$ in $\mathrm{SST}^{-l-}$ mice $\left(n=11\right.$ for $\mathrm{SST}^{+/+}, n=17$ for SST $\left.{ }^{-I-}, P<0.003\right)$. This difference was statistically significant $(P<0.05)$ over the whole interval tested ( $1 \mathrm{~h}$ post tetani). In the same experimental specimens, $1 \mathrm{~h}$ after induction of LTP, paired-pulse facilitation was not significantly different between genotypes (Fig. 4B).

\section{Hippocampal synaptic transmission after cysteamine-induced somatostatin depletion}

As in the course of the behavioral experiments, synaptic transmission was next tested after the application of cysteamine (50 $\mathrm{mg} / \mathrm{kg}$ i.p.) in $\mathrm{C} 57 \mathrm{Bl} / 6$ mice. Slices were prepared $4 \mathrm{~h}$ after injection of the drug to ensure maximal depletion of somatostatin, and specimens obtained after cysteamine injection were com-

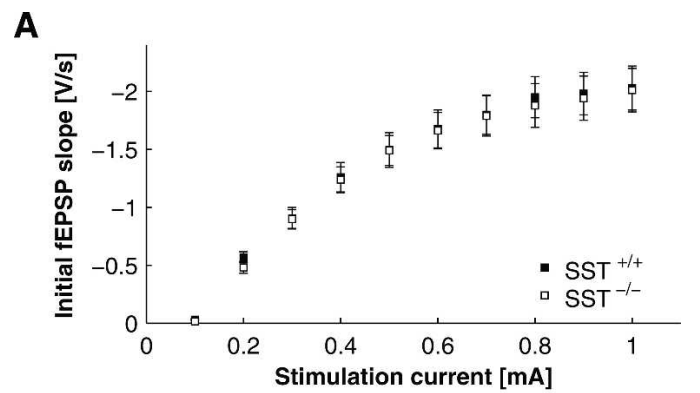

B

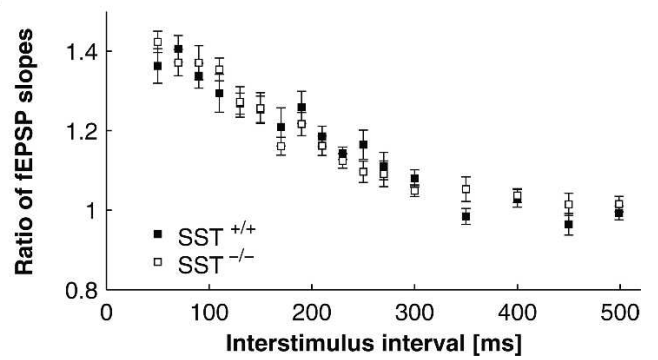

Figure 3. Basal hippocampal synaptic transmission in $\mathrm{SST}^{+/+}$and $\mathrm{SST}^{-1-}$ mice. Field EPSPs were determined in CA1 in response to Schaffer-collateral stimulation. $(A)$ Input-output relationships, with fEPSP slope plotted against stimulation intensity. Note the lack of differences between genotypes. (B) Responses to paired pulse stimulation, with interstimulus intervals (ISIs) varied between 50 and $500 \mathrm{msec}$. Plotted is the ratio of the second to the first response against ISI. Note paired pulse facilitation at short ISIs and lack of difference between genotypes. $P>0.05$ for all values in $\mathrm{SST}^{+/+}$vs. $\mathrm{SST}^{-/-}$mice.

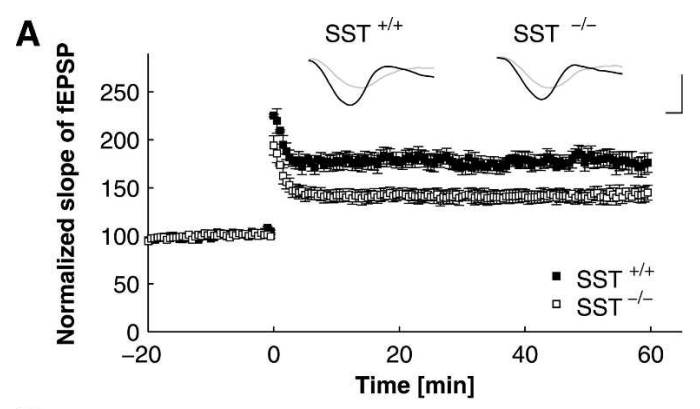

B

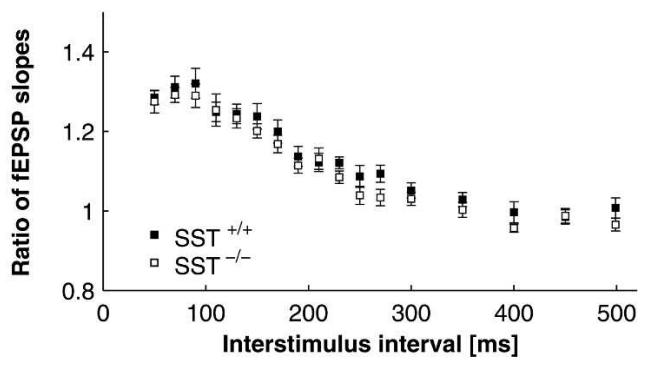

Figure 4. CA1-LTP and paired-pulse facilitation after LTP-induction in $\mathrm{SST}^{+/+}$and $\mathrm{SST}^{-1-}$ mice. (A) Field EPSPs in CA1 in response to Schaffercollateral stimulation at $1 / 30 \mathrm{~Hz}$, with tetanic stimulation (three trains of 50 pulses at $100 \mathrm{~Hz}$; 30 -sec interval between trains) applied at times zero. Tetanic stimulation induced stable LTP, which was significantly smaller in amplitude in $\mathrm{SST}^{-1-}$ as compared with $\mathrm{SST}^{+/+}$animals. All but the first value post tetani were significantly different between genotypes for $1 \mathrm{~h}$ after induction of LTP $(P<0.05$ in Student's $t$-test). Representative voltage traces illustrate responses before (gray traces) and after (black traces) tetanization in slices obtained from $\mathrm{SST}^{+/+}$and $\mathrm{SST}^{-1-}$ mice, as indicated. Traces are scaled to baseline fEPSP amplitude to allow for better comparison of fEPSP slopes. Scale bars: $10 \mathrm{msec}$ in horizontal, and unit baseline amplitude in vertical direction. (B) Responses to paired-pulse stimulation, with interpulse intervals varied between 50 and $500 \mathrm{msec}$, determined $1 \mathrm{~h}$ after induction of LTP. Plotted is the ratio of the second to the first response (fEPSP slope) against interstimulus interval (ISI). Note paired-pulse facilitation similar to that in Fig. $3 \mathrm{~B}$, and the lack of difference between genotypes. $P>0.05$ for all ISIs in $\mathrm{SST}^{+/+} \mathrm{vs} \mathrm{SST}^{-/-}$mice.

pared with saline-injected controls. In CA1, basal synaptic transmission, determined as input-output curves, was not significantly different between slices obtained from cysteamine-treated animals and saline-injected controls (Fig. 5A; $P>0.45$ for all stimulation intensities). In the same slices, LTP was reduced similarly to that observed in SST ${ }^{-1-}$ mice. The fEPSP slope $20 \mathrm{~min}$ after induction of LTP was $196.45 \% \pm 0.10 \%(n=4)$ for salinetreated and $145.47 \% \pm 0.076 \%(n=5)$ for cysteamine-treated C57Bl/6 mice (Fig. 5B; $P<0.01$ ). Again, to control for unspecific effects of cysteamine other than somatostatin depletion (Millard et al. 1983; Pitkanen et al. 1989), slices were prepared from cysteamine-treated $\mathrm{SST}^{-1-}$ mice. The properties of the LTP in $\mathrm{SST}^{-1-}$ mice after cysteamine treatment were indistinguishable from those observed in $\mathrm{C} 57 \mathrm{Bl} / 6$ mice after cysteamine treatment (Fig. 5B) and in untreated SST ${ }^{-1-}$ animals (Fig. 5C; fEPSP slope 20 min after induction of LTP was $142.17 \% \pm 0.062 \%$ for untreated $\mathrm{SST}^{-/-}$mice $[n=17]$ and $149.82 \% \pm 0.073 \%$ for cysteamineinjected $\mathrm{SST}^{-/-}$animals $\left.[n=12]\right)$.

\section{Discussion}

Our data demonstrate an impairment of foreground and background contextual, but not cued, fear conditioning in mice with targeted ablation of the somatostatin gene. Alongside these alterations of emotional memory, we observed a marked reduction of long-term potentiation (LTP) in hippocampal CA1, a brain region crucial for contextual, but not for cued, fear conditioning. 
A
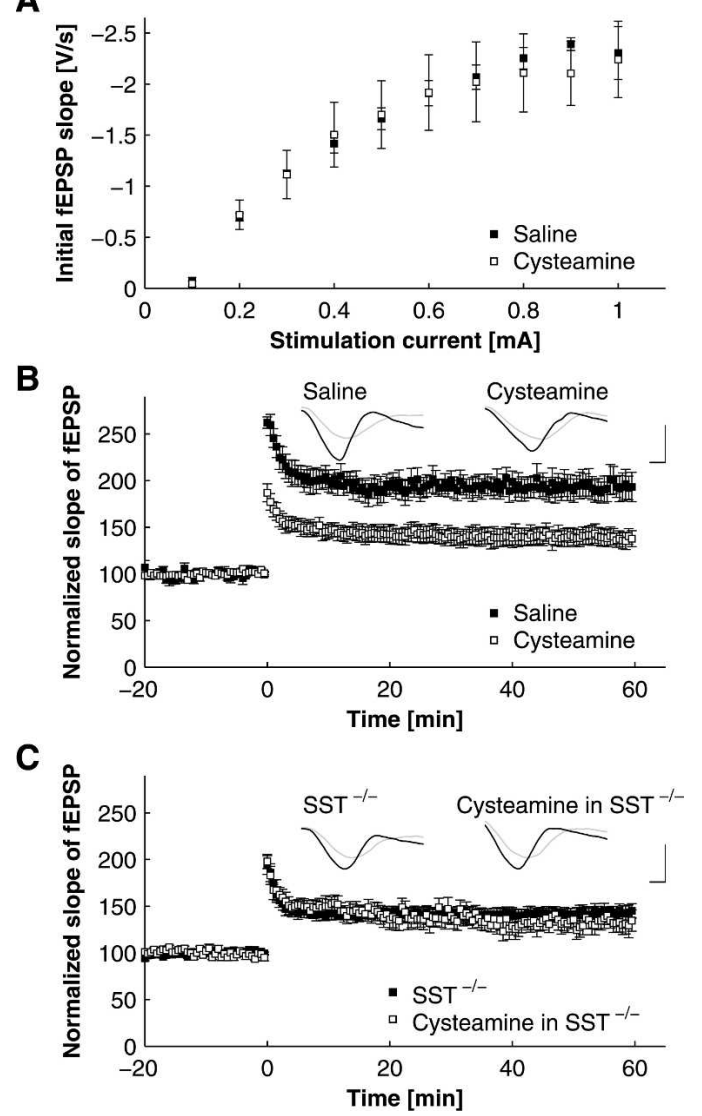

Figure 5. Effects of pharmacological depletion of somatostatin by application of cysteamine on CA1-LTP. (A) Input-output relationships, with fEPSP slope plotted against stimulation intensity. Note the lack of differences between slices obtained from animals treated with either saline or cysteamine, as indicated $(P>0.45$ for all stimulation intensities in Student's $t$-test). (B) LTP in CA1 of C57BI/6 mice ex vivo, with slices prepared $4 \mathrm{~h}$ after application of cysteamine $(50 \mathrm{mg} / \mathrm{kg}$ i.p. $)$ and in a saline-injected control group. Note the reduction of LTP after cysteamine application. All post-tetanic values were significantly different across groups $(P<0.05$ for all time points post tetani, Student's $t$-test). Representative voltage traces illustrate responses before (gray traces) and 30 min after (black traces) tetanization obtained in slices from animals after saline and cysteamine treatment, as indicated. Traces are scaled to baseline fEPSP amplitude to allow for better comparison of fEPSP slopes. Scale bars: $10 \mathrm{msec}$ in horizontal, and unit baseline amplitude in vertical direction. (C) LTP in CA1 ex vivo $4 \mathrm{~h}$ after application of cysteamine $\left(50 \mathrm{mg} / \mathrm{kg}\right.$ i.p.) in $\mathrm{SST}^{-1-}$ mice and in a pharmacologically naïve $\mathrm{SST}^{-1-}$ control group. Application of cysteamine to $\mathrm{SST}^{-1-}$ animals did not result in a further reduction of LTP as compared with untreated SST ${ }^{-1-}$ mice. Induction protocol for LTP in $B$ and $C$ is as in Fig. 4A. Representative voltage traces illustrate responses before (gray traces) and after (black traces) tetanization in slices obtained from $\mathrm{SST}^{-1-}$ mice treated with cysteamine and in untreated $\mathrm{SST}^{-1-}$ controls. Traces are scaled to baseline fEPSP amplitude. Scale bars are as in $B$.

Both the behavioral and the electrophysiological phenotypes could be mimicked in wild-type mice through acute pharmacological somatostatin depletion, which furthermore revealed the peptide's critical importance for the acquisition, but not the consolidation, of fear memory.

Previous animal studies have provided somewhat contradictory evidence concerning the role of somatostatin in memory formation. On the one hand, a positive correlation between performance in hippocampus-dependent learning tasks and the amount of endogenously expressed somatostatin has been observed in various studies (Nilsson et al. 1993; Nakagawasai et al.
2000, 2003). Moreover, intracerebroventricular application of somatostatin facilitated memory and comprised a mitigating effect upon experimentally induced retrograde amnesia (Vecsei et al. 1983, 1984; Lamirault et al. 2001). Also, depletion of somatostatin through application of cysteamine (Szabo and Reichlin 1981) impaired hippocampus-dependent memory performance in a variety of tasks including passive and active avoidance learning (Bakhit and Swerdlow 1986; Haroutunian et al. 1987; Schettini et al. 1988; DeNoble et al. 1989; Vecsei and Widerlov 1990; Matsuoka et al. 1994), as well as water and radial maze paradigms (Fitzgerald and Dokla 1989; Matsuoka et al. 1995; Guillou et al. 1998). However, some studies indicate opposite effects of intrahippocampal injections of cysteamine on hippocampusdependent tasks (Guillou et al. 1998, 1999). Alongside these behavioral data, electrophysiological investigations have shown that depletion of somatostatin diminishes certain forms of LTP in rat hippocampal CA1 in vitro (Rostampour et al. 2002b), whereas in the dentate gyrus, LTP was diminished by application of somatostatin (Baratta et al. 2002). From this literature background, a number of questions arise: (1) Does somatostatin enhance or impair hippocampus-dependent memory performance? (2) Is the effect on hippocampal function brought about by direct somatostatin actions on hippocampal function or does it indirectly arise from other brain regions, possibly from the amygdala, which is particularly rich in somatostatin (McDonald and Mascagni 2002; Sosulina et al. 2006)? (3) Does somatostatin contribute to hippocampus-independent forms of memory as well?

Therefore, we investigated the potential involvement of somatostatin in the mostly amygdala-dependent cued and the amygdala- and hippocampus-dependent contextual fear conditioning paradigms. We observed that while the latter was markedly impaired in the absence of somatostatin, no deficits in the former were evident in $\mathrm{SST}^{-/-}$mice or cysteamine-treated animals. The somatostatin depleting agent cysteamine has frequently been employed to induce an acute somatostatin deficiency, but its usefulness in memory studies has been hampered by the fact that cysteamine also affects prolactin, dopamine, and noradrenaline levels in the mammalian brain (Millard et al. 1983; Pitkanen et al. 1989). With the availability of SST ${ }^{-1-}$ mice, however, it has now become possible to overcome this limitation. In fact, contextual fear memory deficits in $\mathrm{SST}^{-1-}$ mice were not only mimicked by acute application of cysteamine to wild-type mice, but, importantly, memory was also not further impaired when cysteamine was applied to the mutants. On the one hand, this strongly suggests an acute involvement of somatostatin in fear memory formation and excludes a potential contribution of developmental deficits in the $\mathrm{SST}^{-1-}$ mice. On the other hand, this combined approach confirms the specific involvement of somatostatin-dependent mechanisms in the amnestic actions of pre-training cysteamine administration because it strongly argues against cysteamine effects other than somatostatin depletion mediating the effects observed. Moreover, our data suggest that somatostatin exerts a gene-dosage dependent influence on contextual fear memory since $\mathrm{SST}^{+/-}$mice showed an intermediate performance when compared with their wild-type and homozygously gene-ablated littermates. Complete loss of somatostatin entirely disrupted contextual fear memory in both background and foreground conditioning tasks. The observed residual freezing behavior in $\mathrm{SST}^{-/-}$mice was not different from the pre-conditioning levels in contextually habituated animals, indicating that this merely reflects an adaptive response to the context itself, rather than true fear learning (Frankland et al. 1998; Anagnostaras et al. 1999). In fact, $\mathrm{SST}^{-/-}$mice failed to further increase their performance above the initial level in subsequent sessions. Hence, the decreased somatostatin levels not only resulted in a dose-dependent impairment of contextual fear 
learning but, from our results, we even conclude that somatostatin appears to be indispensable for the acquisition of contextual fear memory.

In contrast to the results presented here, one previous study found no differences in cued or contextual fear learning between wild-type and SST ${ }^{-1-}$ mice (Zeyda et al. 2001). There are several possible explanations for these differences. First, Zeyda and coworkers maintained the SST ${ }^{-1-}$ mutation on a $129 / \mathrm{Sv}$ background and used $\mathrm{F}_{2}$ offspring for the behavioral studies. In the present study, animals originated from breeding $\mathrm{SST}^{+/-}$mice backcrossed for 10 generations into the $\mathrm{C} 57 \mathrm{BL} / 6 \mathrm{~J}$ inbred mouse strain. Since it has been shown that inbred mouse strains may differ in their associative learning performance, the discrepancies observed may be due to the altered genetic background (Stiedl et al. 1999; Smith et al. 2007). Second, different training procedures were employed in the two studies. The training paradigms used in the present study match those proven to yield robust and specific conditioned fear responses that can be precisely described by freezing behavior in the C57BL/6J mouse strain (Laxmi et al. 2003). While a detailed investigation of performance in different training paradigms and response specificity was not attempted in the study of Zeyda et al. (2001), a most evident difference relates to the amplitude of the unconditioned stimulus (US) used $(0.7 \mathrm{~mA}$ compared with $0.2 \mathrm{~mA}$ in the present study). With increasing training saliency, conditioned fear responses are no longer adequately described by freezing behavior, but by the cumulative value of risk assessment, freezing, and flight behavior (Laxmi et al. 2003). Moreover, the fear conditioning experiments in the study by Zeyda et al. (2001) were last in a battery of behavioral tests, which might have mitigated the behavioral effects as observed in our present study.

The specificity of memory deficits for contextual conditioning is quite remarkable and indicates a particular involvement of hippocampal processes, since it has been demonstrated that contextual fear conditioning, unlike cued conditioning, crucially depends upon the hippocampus, while the amygdala is commonly believed to be indispensable for both processes (Phillips and LeDoux 1992; Anagnostaras et al. 2001; Goosens and Maren 2001). Besides its role in hippocampus-dependent forms of memory formation, somatostatin has previously also been indicated to be involved in hippocampus-independent memory processes. SST ${ }^{-1-}$ mice, e.g., were remarkably impaired in a motor learning task (Zeyda et al. 2001), and previous publications have raised the issue that some observed effects of somatostatin on memory formation might at least partly be due to an affected motor performance. Most of the above-mentioned studies, however, employed a passive avoidance-learning paradigm (Haroutunian et al. 1987; DeNoble et al. 1989; Vecsei et al. 1989), which does not allow for a discrimination of the impact of somatostatinergic processes onto locomotor behavior from the peptide's role in memory processes. In contrast, the comparative analysis of cued and contextual fear memory formation employed in the present work allowed us to rule out a significant motor impairment in $\mathrm{SST}^{-1-}$ mice. If an altered motor performance was the cause of the freezing deficits observed, freezing behavior in the cued memory paradigm should have been reduced as well. As this is not the case, we are confident to exclude this possibility.

We further aimed to differentiate the potential role of somatostatin in acquisition and consolidation of fear memory. Ablation in $\mathrm{SST}^{-1-}$ mice and pre-training depletion with cysteamine, in particular due to its long half-life (Sagar et al. 1982), are likely to interfere with somatostatinergic processes during both memory acquisition and memory consolidation (Abel and Lattal 2001; Anagnostaras et al. 2001; Rodrigues et al. 2004). In our experiments, only pre-training, but not immediate post-training, infusion of cysteamine selectively interfered with contextual fear memory formation. Hence, our data suggest that somatostatin exerts its impact primarily on the process of fear memory acquisition rather than at the stage of memory consolidation. Posttraining cysteamine, however, produced a generalized increase in fear responding in both $\mathrm{SST}^{+/+}$and $\mathrm{SST}^{-/-}$mice, which thus cannot be attributed to its function as a depletor of somatostatin and might instead relate to a decrease of prolactin, dopamine, and noradrenalin levels in the mammalian brain (Millard et al. 1983; Pitkanen et al. 1989).

Finally, we investigated potential deficits in synaptic plasticity related to these behavioral phenomena. Here, we observed a specific disturbance of the induction of hippocampal LTP in $\mathrm{SST}^{-1-}$ mice and upon cysteamine treatment. Again, there was no further impairment of LTP when cysteamine was applied to the null mutants. The unaltered input-output relationship in both $\mathrm{SST}^{-1-}$ and cysteamine-treated animals and the absence of a somatostatin-related difference in the kinetics of paired-pulse facilitation further indicates that somatostatin depletion selectively interfered with processes of long-term synaptic plasticity, leaving baseline synaptic transmission unaffected. Whilst the relation of amygdalar LTP and cued fear memory is firmly established (McKernan and Shinnick-Gallagher 1997; Rogan et al. 1997), the involvement of CA1-LTP in contextual fear memory formation has been less well-documented. Correlative evidence stems from a study that reported enhancement of both hippocampal LTP and contextual fear memory after acute stress (Blank et al. 2002). More recently, intensive fear conditioning has been shown to interfere with hippocampal LTP (Li et al. 2005). In line with these reports, our observations also point toward a possible functional relation of hippocampal plasticity and contextual fear memory. In turn, our finding of decreased LTP in CA1 upon somatostatin deficiency seems at odds with previous observations of an increase in basal synaptic transmission and shortterm plasticity, but unaltered LTP, after sst2 gene invalidation (Dutar et al. 2002). It should be kept in mind, however, that multiple somatostatin receptors are expressed in the hippocampus, and that compensatory changes may occur after invalidation of the somatostatin gene (Cammalleri et al. 2006) and possibly also the sst2 gene. The combination of genetic and pharmacological experiments, however, enabled us to control for such compensations, and to investigate the net effect of somatostatin on hippocampal plasticity, critical for our behavioral findings.

Also, cysteamine has been reported to alter slice excitability, leading to a decrease in the amplitude of the CA1 population spike under baseline conditions as well as a reduction of certain forms of pharmacologically induced synaptic plasticity and epileptiform discharges (Rostampour et al. 2002a). It is important to note, however, that this study applied $200 \mathrm{mg} / \mathrm{kg}$ of the drug subcutaneously $13 \mathrm{~h}$ before slice preparation from rats, as opposed to $50 \mathrm{mg} / \mathrm{kg}$ intraperitoneally, $4 \mathrm{~h}$ prior to preparation of slices in the present experiments. In fact, no differences in baseline synaptic transmission were evident in response to cysteamine or saline treatment (Fig. 5A). These findings argue against the possibility that an effect of cysteamine on slice excitability brought about the reduction in LTP.

It is interesting to note that in the hippocampus, somatostatin has primarily been localized to a particular class of interneurons, the oriens-lacunosum moleculare (O-LM) interneurons (Maccaferri and McBain 1995; Freund and Buzsaki 1996; Ang et al. 2005). Beyond the modulation of activity in the strata lacunosum/moleculare and radiatum (Baraban and Tallent 2004), these O-LM neurons are of critical importance for septohippocampal interactions and are fire phase-locked to the hippocampal theta cycle (Klausberger et al. 2003), a physiological hallmark of hippocampal function. Previously, application of so- 
matostatin into the medial septum/diagonal band of BROCA has been shown to elicit a shift of hippocampal theta from type 1 (6-9 Hz) toward type 2 (1-6 Hz) frequencies (Bassant et al. 2005). Such increase in theta type 2 power and a concomitant increase in synchrony in this band typifies amygdalo-hippocampal network activity during the consolidation phase of fear memory (Seidenbecher et al. 2003; Narayanan et al. 2007a) and also during contextual memory reconsolidation (Narayanan et al. 2007b). Modulation of theta network activity, in turn, in a working-memory task has been shown to modulate the strength of hippocampal LTP (McCartney et al. 2004). Thus, it is tempting to speculate that somatostatin, possibly released from O-LM neurons, may be able to coordinate local synaptic plasticity with the activity of extended networks during different stages of memory formation.

\section{Concluding remarks and future perspectives}

In conclusion, our data suggest that the somatostatin system plays a critical and strictly dosage-dependent role in the acquisition of contextual fear memory, but not tone fear learning. One mediator of this influence might be long-term synaptic plasticity in the CA1 region, highlighting the involvement of the hippocampus in the processing of complex multimodal, i.e., contextual information during fear memory acquisition and the involvement of somatostatin therein. Somatostatin-containing O-LM interneurons could contribute to these processes. It remains to be determined how the somatostatin system is involved in the shaping of network activity patterns during different stages of fear memory formation.

\section{Materials and Methods}

\section{Animals}

Behavioral experiments under pharmacologically naïve conditions were performed with 8 - to 12 -wk-old male and female $\mathrm{SST}^{-1-}$ mice, $\mathrm{SST}^{+/-}$mice, and wild-type $\left(\mathrm{SST}^{+/+}\right)$littermates (Zeyda et al. 2001), except for electrophysiological experiments in which only male animals have been considered. All animals originated from breeding of $\mathrm{SST}^{+/-}$mice maintained on a C57BL/ $6 \mathrm{~J}$ genetic background by backcrossing for 10 generations, genotyped by PCR analysis of DNA isolated from tail cuts. For pharmacological experiments, either male C57BL/6J OlaHsd mice, obtained at an age of 6-7 wk (Harlan Winkelmann), or male SST ${ }^{-1-}$ mice (derived from mating of SST ${ }^{-1-}$ mice) were used.

At least 1 wk before the start of the experiments, animals were housed individually in a climate-controlled vivarium (Ebeco) under a $12 \mathrm{~h}$ light/dark cycle (lights on at 7 p.m.), with food and water available ad libitum. All experiments were performed between 9:00 a.m. and 6:00 p.m. according to NIH guidelines and regulations through the German law, and were approved by the Regierungspräsidium Dessau (42502/2-441) and the Bezirksregierung Münster (AZ 50.0835.1.0, G 53/2005).

\section{Training apparatus}

The training apparatus (TSE) comprised an acrylic glass arena $(16 \times 32 \times 20 \mathrm{~cm})$ with a grid floor for delivery of electric foot shocks. It was enclosed in an isolation cubicle equipped with a loudspeaker, a ventilation fan providing background noises, as well as house light modules and was located in a brightly lit room. The chamber was always cleaned with $80 \%$ ethanol between animals.

\section{Behavioral data collection}

For all experiments, behavior was monitored using a video camera mounted centrally above the training compartment. Evaluation of behavioral data was conducted off-line by an experimenter who was blind with respect to the experimental protocol, using a timeline version of the public domain program Wintrack.
Freezing (as the measure of fear response) was defined as complete immobilization except for respiratory movements.

\section{Fear conditioning}

\section{Cued fear conditioning}

\section{Adaptation}

On two consecutive days before cued fear conditioning took place, mice were familiarized with the training environment in two adaptation sessions per day. During each of these adaptation sessions, mice were pre-exposed to the context for $2 \mathrm{~min}$ and subsequently received six auditory stimuli $(\mathrm{CS}-; 2.5 \mathrm{kHz}, 85 \mathrm{~dB}$ SPL for $10 \mathrm{sec}$ ) separated by an interstimulus interval (ISI) of 20 sec.

\section{Conditioning}

On the next day, mice received a 4-min fear conditioning session: After an initial 2-min period in which baseline behavior was recorded, mice were confronted with the conditional tone stimulus (CS+; $10 \mathrm{kHz}$ tone, $85 \mathrm{~dB}$ for $10 \mathrm{sec}$ ), co-terminating with a foot shock (1 sec, $0.2 \mathrm{~mA})$.

\section{Retrieval}

Twenty-four hours after training, fear memory was assessed during a retrieval session: After 2 min of exposure to the training apparatus, mice were faced with four CS - and $4 \mathrm{CS}+$ stimuli consecutively, each separated by an ISI of 20 sec. Fear behavior was evaluated for the entire session: Time before tone presentations served for (background) context analysis, whereas time during stimulus presentations (including pauses between stimuli) was used for estimation of CS - and CS+ behavior, respectively.

\section{Contextual fear conditioning}

\section{Conditioning}

For (foreground) contextual fear conditioning, mice were placed in the training apparatus for a period of $4 \mathrm{~min}$. After 2 min of baseline behavior monitoring, an unsignaled foot shock (1 sec, $0.2 \mathrm{~mA}$ ) occurred. This procedure was repeated on three consecutive days (days 1-3).

\section{Retrieval}

On the last day (day 4), mice were re-exposed to the training environment for $2 \mathrm{~min}$. Pre-shock periods on days 2 and 3, as well as the retrieval session on day 4 , were used to determine (foreground) contextual memory performance and are referred to as retrievals $1-3$ in the text.

\section{Pharmacology}

All pharmacological experiments were carried out using the cued fear-conditioning protocol as described above. To achieve efficient somatostatin depletion during memory acquisition, cysteamine (2-mercaptoethylamine-hydrochloride, Sigma) was intraperitoneally injected to C57Bl/6 mice $4 \mathrm{~h}$ before fear conditioning training (Szabo and Reichlin 1981). In the course of the electrophysiological experiments, this procedure was paralleled by cysteamine application $4 \mathrm{~h}$ prior to slice preparation. To investigate a putative influence of somatostatin depletion on memory consolidation, cysteamine was administered $10 \mathrm{~min}$ after the training. In order to verify the cysteaminergic effects, all pharmacological experiments were repeated under identical conditions using $\mathrm{SST}^{-1-}$ mice. In all pharmacological experiments, three experimental groups were compared, which received either $50 \mathrm{mg} / \mathrm{kg}$ or $150 \mathrm{mg} / \mathrm{kg}$ cysteamine, or saline as control (Haroutunian et al. 1987), except for the electrophysiological experiments, in which only $50 \mathrm{mg} / \mathrm{kg}$ was tested.

\section{Statistical analysis}

For the behavioral experiments, raw data were converted to a percentage of total observations (freezing percentage $=$ [total freezing time/total testing time] $\times 100 \%$ ). All experiments performed were evaluated by means of repeated measures analysis of 
variance (RANOVA), using the test sessions as within-subject factor and genotype and gender or pharmacological treatment as between-subject factors. If main effects reached the significance criterion $(P<0.05)$, data were analyzed separately for each training session by ANOVA followed by Fischer's protected least significant difference (PLSD) test for post hoc comparison. All data are expressed as means \pm SEM. For brevity, uninformative nonsignificant interactions were omitted from the text.

\section{Extracellular field-potential recordings}

Horizontal slices containing the dorsal hippocampus of C57Bl/6J or SST ${ }^{-1-}$ mice (postnatal week 8-14) were prepared using standard techniques as previously described for the rat (Szinyei et al. 2003). Briefly, mice were anaesthetized with isoflurane and killed by decapitation. After preparation and equilibration of $400-\mu \mathrm{m}$ thick slices in a sucrose-containing solution $(20 \mathrm{mM}$ piperazine$\mathrm{N}, \mathrm{N}^{\prime}$-bis-2-ethanesulfonate, $2.4 \mathrm{mM} \mathrm{KCl}, 0.5 \mathrm{mM} \mathrm{CaCl}_{2}, 10 \mathrm{mM}$ $\mathrm{MgSO}_{4}, 10 \mathrm{mM}$ glucose, $195 \mathrm{mM}$ sucrose, $\mathrm{pH}$ adjusted to 7.25 with $1 \mathrm{M} \mathrm{NaOH}$ and saturated with $\mathrm{O}_{2}$ ), recordings were obtained under visual guidance (Axioskop FS2 plus, Achroplan 40/w, Zeiss). Experiments were carried out at $30^{\circ} \mathrm{C}$ in a submerged-type chamber. The extracellular solution contained the following concentration of chemicals: $125 \mathrm{mM} \mathrm{NaCl}, 2.5 \mathrm{mM} \mathrm{KCl}, 1.25 \mathrm{mM}$ $\mathrm{NaH}_{2} \mathrm{PO}_{4}, 22 \mathrm{mM} \mathrm{NaHCO}_{3}, 2 \mathrm{mM} \mathrm{MgSO}_{4}, 2 \mathrm{mM} \mathrm{CaCl}_{2}, 20 \mathrm{mM}$ glucose, $\mathrm{pH}$ adjusted to 7.3-7.4 through bubbling with $95 \% \mathrm{O}_{2}$, $5 \% \mathrm{CO}_{2}$. Extracellular field recordings using standard patch pipettes, pulled from borosilicate glass (2-3 M $\Omega$, GC150T-10, Clark Electromedical Instruments) and filled with extracellular solution, were obtained from the stratum radiatum of the CA1 region. In order to stimulate the Schaffer-collaterals, concentric bipolar tungsten stimulation electrodes (FHC) were placed in the stratum radiatum of the CA1 region near the border to CA2. Symmetrical biphasic stimuli (200- $\mu$ sec pulse duration, 0.1-1 $\mathrm{mA}$, interstimulus interval: $30 \mathrm{sec}$ ) were applied to evoke synaptic responses that were amplified using a HEKA EPC10 double patch clamp amplifier (HEKA Elektronik Dr. Schulze GmbH) and a second differential amplifier in linear mode (Science Products). Data were acquired with HEKA pulse software (HEKA Elektronik Dr. Schulze $\mathrm{GmbH}$ ), which, besides controlling all functions of the EPC 10, also triggered a Master 8 programmable stimulation device (A.M.P.I.). Stimulation amplitude was determined by two IsoFlex stimulus isolators (A.M.P.I.) operated in constant current mode. Data were low-pass filtered at $2 \mathrm{kHz}$ with the amplifier's Bessel filter and digitized at $10 \mathrm{kHz}$ by the built-in $\mathrm{AD}$-converter of the EPC 10. After obtaining a stable signal of satisfactory amplitude $(>1 \mathrm{mV})$, an input-output protocol was run to characterize the intrinsic properties of each slice. The stimulation current eliciting $\sim 35 \%$ of the maximal initial slope of the fEPSP (calculated by linear fit using HEKA pulse) was selected for baseline recording.

\section{LTP induction}

Early long-term potentiation was induced by application of three stimulation trains, each consisting of 50 stimuli at $100 \mathrm{~Hz}$, delivered at an interval of $30 \mathrm{sec}$, and monitored for at least $1 \mathrm{~h}$ post tetani.

\section{Electrophysiological data analysis}

The slope of the fEPSP was monitored online using HEKA pulse software and confirmed by offline measurements. Slope values were stored in ASCII text format and imported into Microsoft Excel XP for further statistical analysis. Data were normalized to baseline average slope calculated from the $20 \mathrm{~min}$ prior to tetanization. Groups were compared using Student's two tailed $t$-test, and differences were considered significant when $P<0.05$.

During recording and offline analysis, the experimenter was blind to animal genotype and/or pharmacological treatment, respectively.

\section{Acknowledgments}

We thank M. Wolff, E. Friedl, and S. Ruppel for animal care, T. Broicher and A. Albrecht for helpful discussions, P. Meuth for comments on the figures, and S. Sangha for critical comments on the manuscript. This work was supported by grants of the Deutsche Forschungsgemeinschaft (Pa 336/15-1, H.C.P.), the MaxPlanck-Research Award (H.C.P.), and the Science and University Program of the State Sachsonia-Anhalt (H.C.P. and O.S.), as well as scholarships of the German National Merit Foundation (C.S.) and the DFG Graduiertenkolleg 253 "Biological basis of central nervous system diseases" (C.K. and C.S.).

\section{References}

Abel, T. and Lattal, K.M. 2001. Molecular mechanisms of memory acquisition, consolidation and retrieval. Curr. Opin. Neurobiol. 11: $180-187$.

Anagnostaras, S.G., Maren, S., Sage, J.R., Goodrich, S., and Fanselow, M.S. 1999. Scopolamine and Pavlovian fear conditioning in rats: Dose-effect analysis. Neuropsychopharmacology 21: 731-744.

Anagnostaras, S.G., Gale, G.D., and Fanselow, M.S. 2001. Hippocampus and contextual fear conditioning: Recent controversies and advances. Hippocampus 11: 8-17.

Ang, C.W., Carlson, G.C., and Coulter, D.A. 2005. Hippocampal CA1 circuitry dynamically gates direct cortical inputs preferentially at theta frequencies. J. Neurosci. 25: 9567-9580.

Bakhit, C. and Swerdlow, N. 1986. Behavioral changes following central injection of cysteamine in rats. Brain Res. 365: 159-163.

Baraban, S.C. and Tallent, M.K. 2004. Interneuron diversity series: Interneuronal neuropeptides-Endogenous regulators of neuronal excitability. Trends Neurosci. 27: 135-142.

Baratta, M.V., Lamp, T., and Tallent, M.K. 2002. Somatostatin depresses long-term potentiation and $\mathrm{Ca}^{2+}$ signaling in mouse dentate gyrus. $J$. Neurophysiol. 88: 3078-3086.

Bassant, M.H., Simon, A., Poindessous-Jazat, F., Csaba, Z., Epelbaum, J., and Dournaud, P. 2005. Medial septal GABAergic neurons express the somatostatin sst2A receptor: Functional consequences on unit firing and hippocampal theta. J. Neurosci. 25: 2032-2041.

Binaschi, A., Bregola, G., and Simonato, M. 2003. On the role of somatostatin in seizure control: Clues from the hippocampus. Rev. Neurosci. 14: 285-301.

Blank, T., Nijholt, I., Eckart, K., and Spiess, J. 2002. Priming of long-term potentiation in mouse hippocampus by corticotropin-releasing factor and acute stress: Implications for hippocampus-dependent learning. J. Neurosci. 22: 3788-3794.

Cammalleri, M., Cervia, D., Dal Monte, M., Martini, D., Langenegger, D., Fehlmann, D., Feuerbach, D., Pavan, B., Hoyer, D., and Bagnoli, P. 2006. Compensatory changes in the hippocampus of somatostatin knockout mice: Upregulation of somatostatin receptor 2 and its function in the control of bursting activity and synaptic transmission. Eur. J. Neurosci. 23: 2404-2422.

Cook, L.L., Bissette, G., Dole, K., and Nemeroff, C.B. 1989. A critical evaluation of cysteamine as a tool to deplete somatostatin in the rat central nervous system. Endocrinology 124: 855-861.

Davies, P., Katzman, R., and Terry, R.D. 1980. Reduced somatostatin-like immunoreactivity in cerebral cortex from cases of Alzheimer disease and Alzheimer senile dementa. Nature 288: 279-280.

DeNoble, V.J., Hepler, D.J., and Barto, R.A. 1989. Cysteamine-induced depletion of somatostatin produces differential cognitive deficits in rats. Brain Res. 482: 42-48.

Dutar, P., Vaillend, C., Viollet, C., Billard, J.M., Potier, B., Carlo, A.S., Ungerer, A., and Epelbaum, J. 2002. Spatial learning and synaptic hippocampal plasticity in type 2 somatostatin receptor knock-out mice. Neuroscience 112: 455-466.

Fitzgerald, L.W. and Dokla, C.P. 1989. Morris water task impairment and hypoactivity following cysteamine-induced reductions of somatostatin-like immunoreactivity. Brain Res. 505: 246-250.

Frankland, P.W., Cestari, V., Filipkowski, R.K., McDonald, R.J., and Silva A.J. 1998. The dorsal hippocampus is essential for context discrimination but not for contextual conditioning. Behav. Neurosci. 112: $863-874$.

Freund, T.F. and Buzsaki, G. 1996. Interneurons of the hippocampus. Hippocampus 6: 347-470.

Goosens, K.A. and Maren, S. 2001. Contextual and auditory fear conditioning are mediated by the lateral, basal, and central amygdaloid nuclei in rats. Learn. Mem. 8: 148-155.

Guillou, J.L., Micheau, J., and Jaffard, R. 1998. The opposite effects of cysteamine on the acquisition of two different tasks in mice are associated with bidirectional testing-induced changes in hippocampal adenylyl cyclase activity. Behav. Neurosci. 112: 900-908.

Guillou, J.L., Micheau, J., and Jaffard, R. 1999. Intrahippocampal injections of cysteamine improve the retention of a bar-pressing task in mice. Behav. Brain Res. 103: 113-117. 
Haroutunian, V., Mantin, R., Campbell, G.A., Tsuboyama, G.K., and Davis, K.L. 1987. Cysteamine-induced depletion of central somatostatin-like immunoactivity: Effects on behavior, learning, memory and brain neurochemistry. Brain Res. 403: 234-242.

Klausberger, T., Magill, P.J., Marton, L.F., Roberts, J.D., Cobden, P.M., Buzsaki, G., and Somogyi, P. 2003. Brain-state- and cell-type-specific firing of hippocampal interneurons in vivo. Nature 421: 844-848.

Lamirault, L., Guillou, J.L., Micheau, J., and Jaffard, R. 2001. Intrahippocampal injections of somatostatin dissociate acquisition from the flexible use of place responses. Eur. J. Neurosci. 14: $567-570$.

Laxmi, T.R., Stork, O., and Pape, H.C. 2003. Generalisation of conditioned fear and its behavioural expression in mice. Behav. Brain Res. 145: 89-98.

LeDoux, J.E. 2000. Emotion circuits in the brain. Annu. Rev. Neurosci. 23: $155-184$

Li, Z., Zhou, Q., Li, L., Mao, R., Wang, M., Peng, W., Dong, Z., Xu, L., and Cao, J. 2005. Effects of unconditioned and conditioned aversive stimuli in an intense fear conditioning paradigm on synaptic plasticity in the hippocampal CA1 area in vivo. Hippocampus 15: $815-824$

Maccaferri, G. and McBain, C.J. 1995. Passive propagation of LTD to stratum oriens-alveus inhibitory neurons modulates the temporoammonic input to the hippocampal CA1 region. Neuron 15: $137-145$.

Maren, S. and Quirk, G.J. 2004. Neuronal signalling of fear memory. Nat. Rev. Neurosci. 5: 844-852.

Matsuoka, N., Kaneko, S., and Satoh, M. 1991a. A facilitatory role of endogenous somatostatin in long-term potentiation of the mossy fiber-CA3 system in guinea-pig hippocampus. Neurosci. Lett. 129: $177-180$.

Matsuoka, N., Kaneko, S., and Satoh, M. 1991b. Somatostatin augments long-term potentiation of the mossy fiber-CA3 system in guinea-pig hippocampal slices. Brain Res. 553: 188-194.

Matsuoka, N., Maeda, N., Yamaguchi, I., and Satoh, M. 1994. Possible involvement of brain somatostatin in the memory formation of rats and the cognitive enhancing action of FR121196 in passive avoidance task. Brain Res. 642: 11-19.

Matsuoka, N., Yamazaki, M., and Yamaguchi, I. 1995. Changes in brain somatostatin in memory-deficient rats: Comparison with cholinergic markers. Neuroscience 66: 617-626.

McCartney, H., Johnson, A.D., Weil, Z.M., and Givens, B. 2004. Theta reset produces optimal conditions for long-term potentiation. Hippocampus 14: 684-687.

McDonald, A.J. and Mascagni, F. 2002. Immunohistochemical characterization of somatostatin containing interneurons in the rat basolateral amygdala. Brain Res. 943: 237-244.

McKernan, M.G. and Shinnick-Gallagher, P. 1997. Fear conditioning induces a lasting potentiation of synaptic currents in vitro. Nature 390: 607-611.

Millard, W.J., Sagar, S.M., Simpkins, J.W., Owens, R.E., Badger, T.M., Friesen, H.G., and Martin, J.B. 1983. Cysteamine induces depletion of both immunological and biological prolactin activity in the anterior pituitary and blood of the rat. Endocrinology 113: $2161-2167$.

Moller, L.N., Stidsen, C.E., Hartmann, B., and Holst, J.J. 2003 Somatostatin receptors. Biochim. Biophys. Acta 1616: 1-84.

Nakagawasai, O., Tadano, T., Niijima, F., Tan-No, K., and Kisara, K. 2000. Immunohistochemical estimation of rat brain somatostatin on avoidance learning impairment induced by thiamine deficiency. Brain Res. Bull. 51: 47-55.

Nakagawasai, O., Hozumi, S., Tan-No, K., Niijima, F., Arai, Y., Yasuhara, H., and Tadano, T. 2003. Immunohistochemical fluorescence intensity reduction of brain somatostatin in the impairment of learning and memory-related behaviour induced by olfactory bulbectomy. Behav. Brain Res. 142: 63-67.

Narayanan, R.T., Seidenbecher, T., Kluge, C., Bergado, J., Stork, O., and Pape, H.C. 2007a. Dissociated theta phase synchronization in amygdalo-hippocampal circuits during various stages of fear memory. Eur. J. Neurosci. 25: 1823-1831.

Narayanan, R.T., Seidenbecher, T., Sangha, S., Stork, O., and Pape, H.C. $2007 \mathrm{~b}$. Theta resynchronization during reconsolidation of remote contextual fear memory. Neuroreport 18: 1107-1111.

Nilsson, L., Mohammed, A.K., Henriksson, B.G., Folkesson, R., Winblad, B., and Bergstrom, L. 1993. Environmental influence on somatostatin levels and gene expression in the rat brain. Brain Res. 628: 93-98.

Phelps, E.A. and LeDoux, J.E. 2005. Contributions of the amygdala to emotion processing: From animal models to human behavior Neuron 48: 175-187.

Phillips, R.G. and LeDoux, J.E. 1992. Differential contribution of amygdala and hippocampus to cued and contextual fear conditioning. Behav. Neurosci. 106: 274-285

Pitkanen, A., Valjakka, A., Paakkonen, A., Sirvio, J., Jousmaki, V., Partanen, J., and Riekkinen, P.J. 1989. Effect of cysteamine on levels of somatostatin-like immunoreactivity and catecholamines and on electroencephalogram in the rat brain. Neuropeptides 14: $1-9$.

Reisine, T. and Bell, G.I. 1995. Molecular biology of somatostatin receptors. Endocr. Rev. 16: 427-442.

Rodrigues, S.M., Schafe, G.E., and LeDoux, J.E. 2004. Molecular mechanisms underlying emotional learning and memory in the lateral amygdala. Neuron 44: 75-91.

Rogan, M.T., Staubli, U.V., and LeDoux, J.E. 1997. Fear conditioning induces associative long-term potentiation in the amygdala. Nature 390: $604-607$.

Rostampour, M., Fathollahi, Y., Semnanian, S., Hajizadeh, S., Mirnajafizadeh, J., and Shafizadeh, M. 2002a. Cysteamine pre-treatment reduces pentylenetetrazol-induced plasticity and epileptiform discharge in the CA1 region of rat hippocampal slices. Brain Res. 955: 98-103.

Rostampour, M., Fathollahi, Y., Semnanian, S., Hajizadeh, S., Mirnajafizadeh, J., and Shafizadeh, M. 2002b. The ability of hippocampal CA1 area for induction of long-term potentiation is persistently reduced by prior treatment with cysteamine: an in vitro study. Neuropeptides 36: 263-270.

Sagar, S.M., Landry, D., Millard, W.J., Badger, T.M., Arnold, M.A., and Martin, J.B. 1982. Depletion of somatostatin-like immunoreactivity in the rat central nervous system by cysteamine. J. Neurosci. 2: 225-231.

Saito, T., Iwata, N., Tsubuki, S., Takaki, Y., Takano, J., Huang, S.M., Suemoto, T., Higuchi, M., and Saido, T.C. 2005. Somatostatin regulates brain amyloid $\beta$ peptide $A \beta 42$ through modulation of proteolytic degradation. Nat. Med. 11: 434-439.

Schettini, G. 1991. Brain somatostatin: Receptor-coupled transducing mechanisms and role in cognitive functions. Pharmacol. Res. 23: $203-215$.

Schettini, G., Florio, T., Magri, G., Grimaldi, M., Meucci, O., Landolfi, E., and Marino, A. 1988. Somatostatin and SMS 201-995 reverse the impairment of cognitive functions induced by cysteamine depletion of brain somatostatin. Eur. J. Pharmacol. 151: 399-407.

Seidenbecher, T., Laxmi, T.R., Stork, O., and Pape, H.C. 2003. Amygdalar and hippocampal theta rhythm synchronization during fear memory retrieval. Science 301: 846-850.

Smith, D.R., Gallagher, M., and Stanton, M.E. 2007. Genetic background differences and nonassociative effects in mouse trace fear conditioning. Learn. Mem. 14: 597-605.

Sosulina, L., Meis, S., Seifert, G., Steinhauser, C., and Pape, H.C. 2006. Classification of projection neurons and interneurons in the rat lateral amygdala based upon cluster analysis. Mol. Cell. Neurosci. 33: $57-67$.

Stiedl, O., Radulovic, J., Lohmann, R., Birkenfeld, K., Palve, M., Kammermeier, J., Sananbenesi, F., and Spiess, J. 1999. Strain and substrain differences in context- and tone-dependent fear conditioning of inbred mice. Behav. Brain Res. 104: 1-12.

Szabo, S. and Reichlin, S. 1981. Somatostatin in rat tissues is depleted by cysteamine administration. Endocrinology 109: 2255-2257.

Szinyei, C., Stork, O., and Pape, H.C. 2003. Contribution of NR2B subunits to synaptic transmission in amygdaloid interneurons. $J$. Neurosci. 23: 2549-2556.

Vecsei, L. and Widerlov, E. 1990. Preclinical and clinical studies with cysteamine and pantethine related to the central nervous system. Prog. Neuropsychopharmacol. Biol. Psychiatry 14: 835-862.

Vecsei, L., Bollok, I., and Telegdy, G. 1983. Intracerebroventricular somatostatin attenuates electroconvulsive shock-induced amnesia in rats. Peptides 4: 293-295.

Vecsei, L., Bollok, I., Varga, J., Penke, B., and Telegdy, G. 1984. The effects of somatostatin, its fragments and an analog on electroconvulsive shock-induced amnesia in rats. Neuropeptides 4: $137-143$.

Vecsei, L., Pavo, I., Zsigo, J., Penke, B., and Widerlov, E. 1989. Comparative studies of somatostatin-14 and some of its fragments on passive avoidance behavior, open field activity and on barrel rotation phenomenon in rats. Peptides 10: 1153-1157.

Viollet, C., Vaillend, C., Videau, C., Bluet-Pajot, M.T., Ungerer, A., L'Heritier, A., Kopp, C., Potier, B., Billard, J., Schaeffer, J., et al. 2000 Involvement of sst2 somatostatin receptor in locomotor, exploratory activity and emotional reactivity in mice. Eur. J. Neurosci. 12: $3761-3770$

Zeyda, T., Diehl, N., Paylor, R., Brennan, M.B., and Hochgeschwender, U. 2001. Impairment in motor learning of somatostatin null mutant mice. Brain Res. 906: 107-114.

Received October 5, 2007; accepted in revised form January 18, 2008. 


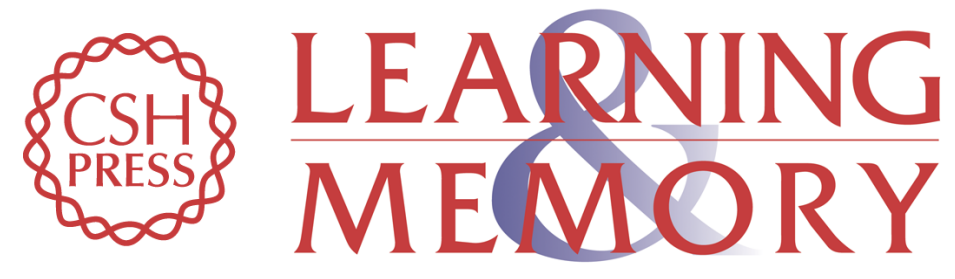

\section{Role of the somatostatin system in contextual fear memory and hippocampal synaptic plasticity}

Christian Kluge, Christian Stoppel, Csaba Szinyei, et al.

Learn. Mem. 2008, 15:

Access the most recent version at doi:10.1101//m.793008

References This article cites 67 articles, 8 of which can be accessed free at:

http://learnmem.cshlp.org/content/15/4/252.full.html\#ref-list-1

License

Email Alerting Receive free email alerts when new articles cite this article - sign up in the box at the Service top right corner of the article or click here. 